\title{
Magnitude of Floods in Northern Idaho, February 1996
}

\section{BACKGROUND}

In early February 1996, a powerful storm swept into the inland Northwest from the Pacific Ocean. Strong, warm winds, several inches of rainfall on heavy mountain snowpack, and ice jams in river channels caused severe floods throughout the Coeur d'Alene, St. Joe, Palouse, and other northern Idaho river basins (fig. 1). Coeur d'Alene Lake also rose more than 8 feet above its normal summertime level. These recent floods, the worst since 1974, forced evacuation of many low-lying areas and extensively damaged public and private property. Fifteen northern Idaho counties were declared Flood Disaster Areas.

The U.S. Geological Survey (USGS) operates more than 40 streamflowgaging and lake-stage recording stations in northern Idaho. Most of these stations are funded by partnerships between the USGS and other Federal, State, tribal, and local agencies and

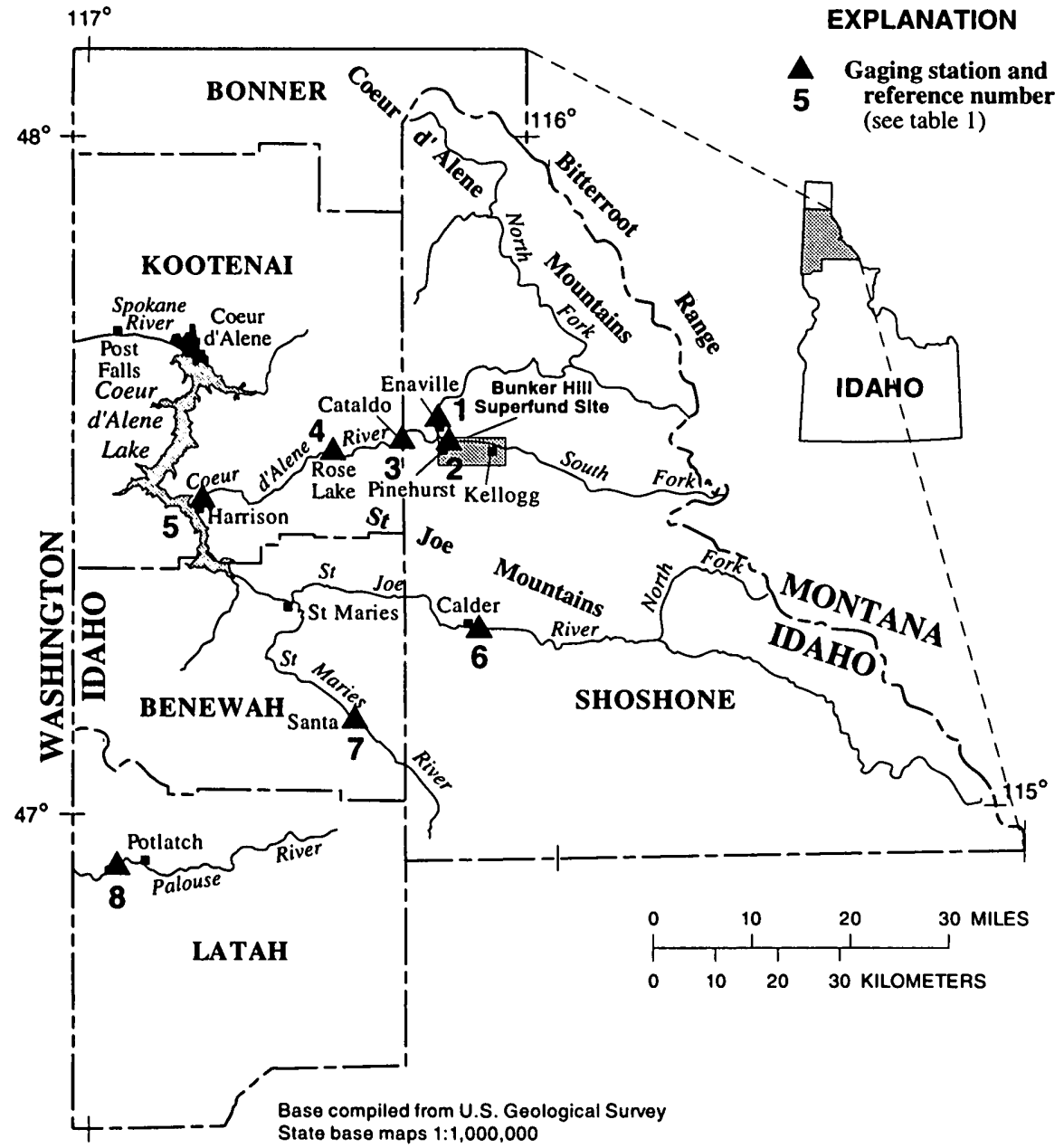

Figure 1. Location of study area. public and private utilities. Data from these stations are crucial for water supply planning; flood forecasting and response; dam and reservoir system operation; and engineering and maintenance of bridges, roads, and other structures.

Some stations provide real-time data through satellite or ground communication links. Data from these stations are used by the National Weather Service and other agencies to forecast river flows, and by local, State, and regional authorities to forecast floods and issue flood warnings.

USGS field crews obtained some of the highest river stage (depth) and discharge (flow) measurements ever recorded at several gaging stations at or near the peak of the floods. These data contribute to understanding flood behavior and enhance efforts to minimize the destructive effects of floods.

\section{MAGNITUDE OF FLOODS}

The magnitudes of flood peaks at selected gaging stations in northern Idaho are shown in table 1. For comparison, table 1 also includes the 100-year flood peak, the mean February flow, the date and magnitude of historical flood peaks, and the number of years of continuous streamflow records that were used to derive the data for each of the gaging stations. The 100 -year flood peak is one that has a 1-percent chance of occurring in any given year. Flood frequency data were computed by fitting the log-Pearson Type III frequency distribution to the data collected through 1996 using procedures recommended by the U.S. Interagency Advisory Committee on Water Data (1982). The gaging stations South Fork Coeur d'Alene River near Pinehurst and Coeur d'Alene River at 
Rose Lake and Harrison did not have sufficient years of record prior to 1996 to substantiate the computation of a 100-year flood peak.

Mean daily flows for the Rose Lake and Harrison gaging stations were computed using a hydraulic model that simulates unsteady open-channel flow in the low-gradient lower reach of the Coeur d'Alene River downstream from Cataldo. This reach is influenced by the level of Coeur d'Alene Lake, where no relation exists between river stage and flow. Model results indicated that the highest mean daily flow for these gaging stations during the February 1996 flood occurred on February 9 (table 1, column 3).

The February 1996 floods were the largest since the mid-January 1974 historical flood. Flood peaks were slightly less than the 100-year flood peaks at all gaging stations except Palouse River near Potlatch (table 1). Flood peaks were 1,800 cubic feet per second $\left(\mathrm{ft}^{3} / \mathrm{s}\right)$ less than the 100 -year flood peak at the North Fork Coeur d'Alene River at Enaville and St. Maries River near Santa gaging stations. Flood peaks at the Coeur d'Alene River at Cataldo and St. Joe River at Calder gaging stations were 2,500 and $4,300 \mathrm{ft}^{3} / \mathrm{s}$ less, respectively, than the 100-year flood peaks. However, the flood peak at the Palouse River near Potlatch gaging station exceeded the 100-year flood peak by $600 \mathrm{ft}^{3} / \mathrm{s}$.

February 1996 flood peaks at three of these five gaging stations were less

Table 1. Magnitude and frequency of the February 1996 flood and historical flood peaks at selected gaging stations, northern Idaho

[Map reference No., locations on figure 1 ; $\mathrm{ft}^{3} / \mathrm{s}$, cubic feet per second; unk, unknown; - , unable to calculate because of insufficient record]

\begin{tabular}{|c|c|c|c|c|c|c|c|}
\hline $\begin{array}{l}\text { Map } \\
\text { refer- } \\
\text { ence } \\
\text { No. }\end{array}$ & $\begin{array}{l}\text { Gaging- } \\
\text { station } \\
\text { No. and name }\end{array}$ & $\begin{array}{l}\text { Measure- } \\
\text { ment date } \\
\text { and time } \\
\text { (24-hour) }\end{array}$ & $\begin{array}{l}\text { February } \\
1996 \\
\text { flood } \\
\text { peak } \\
\left(\mathrm{ft}^{3} / \mathrm{s}\right)\end{array}$ & $\begin{array}{l}\text { 100-year } \\
\text { flood } \\
\text { peak } \\
\left(\mathrm{ft}^{3} / \mathrm{s}\right)\end{array}$ & $\begin{array}{l}\text { Years } \\
\text { of } \\
\text { record } \\
\text { through } \\
1996\end{array}$ & $\begin{array}{l}\text { Mean } \\
\text { February } \\
\text { flow } \\
\left(\mathrm{ft}^{3} / \mathrm{s}\right)\end{array}$ & $\begin{array}{c}\text { Date and } \\
\text { magnitude } \\
\text { of } \\
\text { historical } \\
\text { flood peak } \\
\left(\mathrm{ft}^{3} / \mathrm{s}\right)\end{array}$ \\
\hline 1 & $\begin{array}{l}12413000 \ldots \ldots \ldots \ldots \ldots \ldots \\
\text { North Fork } \\
\text { Coeur d'Alene River } \\
\text { at Enaville }\end{array}$ & $\begin{array}{l}\text { Feb. } 9 \\
1645\end{array}$ & 56,600 & 58,400 & 57 & 2,016 & $\begin{array}{c}\text { Jan. } 16,1974 \\
61,000\end{array}$ \\
\hline 2 & $\begin{array}{l}12413470 \ldots \ldots \ldots \ldots \ldots \ldots \\
\text { South Fork } \\
\text { Coeur d'Alene River } \\
\text { near Pinehurst }\end{array}$ & $\begin{array}{l}\text { Feb. } 9 \\
\text { unk }\end{array}$ & 11,700 & - & 9 & 515 & \\
\hline 3 & $\begin{array}{l}12413500 \ldots \ldots \ldots \ldots \cdots \cdots \\
\text { Coeur d'Alene River } \\
\text { at Cataldo }\end{array}$ & $\begin{array}{l}\text { Feb. } 9 \\
1730\end{array}$ & 68,300 & 70,800 & 63 & 2,495 & $\begin{array}{c}\text { Jan. } 16,1974 \\
79,000\end{array}$ \\
\hline 4 & $\begin{array}{l}12413810 \ldots \ldots \ldots \ldots \ldots \ldots \ldots \\
\text { Coeur d'Alene River } \\
\text { at Rose Lake }\end{array}$ & & ${ }^{2} 50,500$ & - & - & - & \\
\hline 5 & $\begin{array}{l}12413860 \ldots \ldots \ldots \ldots \ldots \cdots \cdots \\
\text { Coeur d'Alene River } \\
\text { at Harrison }\end{array}$ & & ${ }^{2} 47,700$ & - & - & - & \\
\hline 6 & $\begin{array}{l}12414500 \ldots \ldots \ldots \cdots \cdots \cdots \\
\text { St. Joe River } \\
\text { at Calder }\end{array}$ & $\begin{array}{l}\text { Feb. } 9 \\
1200\end{array}$ & 38,700 & 43,000 & 78 & 1,495 & $\begin{array}{c}\text { Dec. } 23,1933 \\
53,000\end{array}$ \\
\hline 7 & $\begin{array}{l}12414900 \ldots \ldots \ldots \ldots \ldots \cdots \\
\text { St. Maries River } \\
\text { near Santa }\end{array}$ & $\begin{array}{c}\text { Feb. } 9 \\
\text { unk }\end{array}$ & 12,300 & 14,100 & 31 & 487 & $\begin{array}{c}\text { Jan. } 5,1974 \\
10,700\end{array}$ \\
\hline 8 & $\begin{array}{l}13345000 \ldots \ldots \cdots \cdots \cdots \cdots \\
\text { Palouse River } \\
\text { near Potlatch }\end{array}$ & $\begin{array}{c}\text { Feb. } 8 \\
\text { unk }\end{array}$ & 14,600 & 14,000 & 35 & 532 & $\begin{array}{c}\text { Jan. } 16,1974 \\
10,100\end{array}$ \\
\hline
\end{tabular}

\section{SELECTED REFERENCES}

Kjelstrom, L.C., 1996, Statistical summaries of streamflow data for selected gaging stations in Idaho and adjacent States through September 1990-Volume 1: Gaging stations with 10 or more years of record: U.S. Geological Survey Water-Resources Investigations Report 94-4069, 533 p.

U.S. Interagency Advisory Committee on Water Data, 1982, Guidelines for determining flood flow frequency, Bulletin 17B of the Hydrology Subcommittee: Reston, Va., U.S. Geological Survey, Office of Water Data Coordination [183 p.].

\section{For more information contact:}

\section{U.S. Geological Survey}

230 Collins Road

Boise, ID 83702-4520

(208) $387-1300$ 